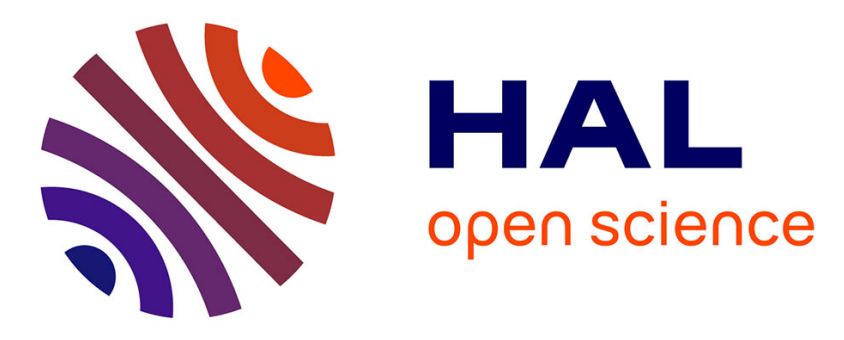

\title{
Catalase-like activity of bovine met-hemoglobin: interaction with the pseudo-catalytic peroxidation of anthracene traces in aqueous medium
}

Paco Laveille, Anne Galarneau, Jullien Drone, Francois Fajula, Carole Bailly, Sylviane Pulvin, Thomas Daniel

\section{To cite this version:}

Paco Laveille, Anne Galarneau, Jullien Drone, Francois Fajula, Carole Bailly, et al.. Catalase-like activity of bovine met-hemoglobin: interaction with the pseudo-catalytic peroxidation of anthracene traces in aqueous medium. Biotechnology Journal, 2009, 4 (10), pp.1460. 10.1002/biot.200900100 . hal-00502451

\section{HAL Id: hal-00502451 \\ https://hal.science/hal-00502451}

Submitted on 15 Jul 2010

HAL is a multi-disciplinary open access archive for the deposit and dissemination of scientific research documents, whether they are published or not. The documents may come from teaching and research institutions in France or abroad, or from public or private research centers.
L'archive ouverte pluridisciplinaire $\mathbf{H A L}$, est destinée au dépôt et à la diffusion de documents scientifiques de niveau recherche, publiés ou non, émanant des établissements d'enseignement et de recherche français ou étrangers, des laboratoires publics ou privés. 


\section{Catalase-like activity of bovine met-hemoglobin: interaction with the pseudo-catalytic peroxidation of anthracene traces in aqueous medium}

\begin{tabular}{|c|c|}
\hline Journal: & Biotechnology Journal \\
\hline Manuscript ID: & biot.200900100.R1 \\
\hline Wiley - Manuscript type: & Research Article \\
\hline $\begin{array}{r}\text { Date Submitted by the } \\
\text { Author: }\end{array}$ & 27-May-2009 \\
\hline Complete List of Authors: & $\begin{array}{l}\text { LAVEILLE, Paco; Institut Charles Gerhard Montpellier, Materiaux } \\
\text { Avancés pour la Catalyse et la Santé UMR } 5253 \\
\text { CNRS/ENSCM/UM2/UM1; Université de Technologie de Compiegne, } \\
\text { Génie Enzymatique et Cellulaire UMR } 6022 \text { CNRS/UTC } \\
\text { Galarneau, Anne; Institut Charles Gerhard Montpellier, Materiaux } \\
\text { Avancés pour la Catalyse et la Santé UMR } 5253 \\
\text { CNRS/ENSCM/UM2/UM1 } \\
\text { Drone, Jullien; Institut Charles Gerhard Montpellier, Materiaux } \\
\text { Avancés pour la Catalyse et la Santé UMR } 5253 \\
\text { CNRS/ENSCM/UM2/UM1 } \\
\text { Fajula, Francois; Institut Charles Gerhard Montpellier, Materiaux } \\
\text { Avancés pour la Catalyse et la Santé UMR } 5253 \\
\text { CNRS/ENSCM/UM2/UM1 } \\
\text { Bailly, Carole; TOTAL France S.A., Centre de Recherches de } \\
\text { Gonfreville } \\
\text { Pulvin, Sylviane; Université de Technologie de Compiegne, Génie } \\
\text { Enzymatique et Cellulaire UMR } 6022 \text { CNRS/UTC } \\
\text { Daniel, Thomas; Universite de Technologie de Compiègne, Genie } \\
\text { Enzymatique et Cellulaire, UMR } 6022 \text { CNRS/UTC }\end{array}$ \\
\hline Keywords: & $\begin{array}{l}\text { Enzyme catalysis, Hemoglobin, Bioremediation process, Polycyclic } \\
\text { Aromatic Hydrocarbons, Promiscuous activity }\end{array}$ \\
\hline
\end{tabular}

\section{S) ScholaroNE \\ Manuscript Central}




\title{
Catalase-like activity of bovine met-hemoglobin: interaction with the pseudo-catalytic peroxidation of anthracene traces in aqueous medium
}

\author{
Laveille Paco $^{[1],[2],[3]}$, Galarneau Anne ${ }^{\star[1]}$, Drone Jullien ${ }^{[1]}$, Fajula François ${ }^{[1]}$, \\ Bailly Carole ${ }^{[2]}$, Pulvin Sylviane ${ }^{[3]^{\star}}$, Thomas Daniel ${ }^{[3]}$
}

Keywords: Enzyme catalysis, hemoglobin, bioremediation process, $\mathrm{PAH}$, promiscuous activity

Abbreviations:

-ABTS 2,2'-azino-bis(3-ethylbenzthiazoline-6-sulphonic acid -ANT Anthracene -CYP Cytochrome P450

- Hb Hemoglobin

-HRP Horeseradish peroxidase

-Met-Hb Met-hemoglobin

-NADPH Nicotinamide adenine dinucleotide phosphate

-PAH Polycyclique Aromatic Hydrocarbons

-UFLC Ultra fast liquid chromatography

\footnotetext{
${ }^{[1]}$ Institut Charles Gerhardt Montpellier,

Equipe des Matériaux Avancés pour la Catalyse et la Santé,

UMR 5253 CNRS/ENSCM/UM2/UM1,

8 rue de l'Ecole Normale 34296 Montpellier cedex 5 France

Fax (+33) 04-67-16-34-70

Tel (+33) 04-67-16-34-68

E-mail : anne.galarneau@enscm.fr

${ }^{[2]}$ TOTAL France

Centre de Recherches de Gonfreville

Z.I. du port autonome du Havre, route industrielle, Carrefour $n^{\circ} 4$ 76700 Rogerville France

${ }^{[3]}$ Université de Technologie de Compiegne équipe du génie enzymatique et cellulaire, UMR 6022 CNRS/UTC B.P. 2052960205 COMPIEGNE cedex France

Fax : 03.44.20.49.51

E-mail : sylviane.pulvin@utc.fr
} 
Hemoglobin is a member of hemoprotein superfamily whose main role is to transport $\mathrm{O}_{2}$ in vertebrate organisms. It has also two known promiscuous enzymatic activities, namely peroxidase and oxygenase. Here we show for the first time that bovine hemoglobin also presents a catalase-like activity characterized by a $V_{\max }$ of 344 $\mu \mathrm{M} / \mathrm{min}$, a $\mathrm{K}_{\mathrm{M}}$ of $24 \mathrm{mM}$ and a $\mathrm{k}_{\mathrm{cat}}$ equal to $115 \mathrm{~min}^{-1}$. For high anthracene and hemoglobin concentrations and low hydrogen peroxide concentrations, this activity inhibits the expected oxidation of anthracene, which occurs through a peroxidase-like mechanism. Anthracene belongs to the polycyclic aromatic hydrocarbons family whose members are carcinogenic and persistent pollutants found in industrial waste waters. Our results show that anthracene oxidation by hemoglobine and hydrogen peroxide follows a typical bi-bi ping-pong mechanism with a $\mathrm{V}_{\max }$ equal to 0.250 $\mu \mathrm{M} / \mathrm{min}, \mathrm{K}_{\mathrm{M}(\mathrm{H} 2 \mathrm{O} 2)}$ of $80 \mu \mathrm{M}, \mathrm{K}_{\mathrm{M}(\mathrm{ANT})}$ of $1.1 \mu \mathrm{M}$ and $\mathrm{k}_{\text {cat }}$ of $0.17 \mathrm{~min}^{-1}$. The oxidation of anthracene is shown to be pseudo-catalytic because an excess of hemoglobin and hydrogen peroxide is required to make $\mathrm{PAH}$ completely disappear. Thus bovine hemoglobin presents, in different degrees, all the catalytic activities of the hemoprotein group which makes it a very interesting protein for biotechnological processes and with which one can study structure-activity relationships. 


\section{Introduction}

Hemoglobin $(\mathrm{Hb})$ is a well-known protein. It is a heterotetramer that consists of two alpha and two beta subunits $\left(\alpha_{2} / \beta_{2}\right)$, each one containing the prosthetic group protoporphyirin IX [1]. This peculiar structure allows $\mathrm{Hb}$ to bind, transport and release oxygen in all vertebrate organisms. Depending on the iron atom oxidation state, different types of $\mathrm{Hb}$ can be found, notably oxy-, deoxy- and met-hemoglobin [2, 3]. The met-hemoglobin (met- $\mathrm{Hb}$ ), produced in vivo through an autoxidation process, is characterized by a ferric ( $\left.\mathrm{Fe}^{\mathrm{III}}\right)$ state of the hemin and is unable to bind oxygen.

$\mathrm{Hb}$ belongs to the hemoprotein super family which includes transport proteins such as globin, responsible for $\mathrm{O}_{2}$ transport and storage, cytochrome, which is responsible for electron transport and nitrophorine, a protein responsible for nitric oxide transport [4] and also three catalytic proteins (enzyme) classes named hemethiolates, peroxidases and catalases.

- Heme-thiolate (EC 1.14) is the recommended collective name for the class of proteins that includes the cytochrome P450 enzymes (CYP). The most common reaction catalyzed by these enzymes is monooxygenation, defined as the insertion of one atom of oxygen into a substrate from molecular oxygen, with the concomitant release of water $[5,6,7,8]$ (Figure 1).

- Peroxidases (EC 1.11.1) use hydrogen peroxide $\left(\mathrm{H}_{2} \mathrm{O}_{2}\right)$ as an electron acceptor to catalyze oxidative reactions $[9,10,11,12,13]$ (Figure 1).

- Catalases, which belong to a sub group of peroxidase (EC 1.11.1.6), catalyze the disproportionation reaction of $\mathrm{H}_{2} \mathrm{O}_{2}$. In this case, $\mathrm{H}_{2} \mathrm{O}_{2}$ acts both as an electron acceptor and an electron donor at the same time. The reaction yields molecular oxygen $\left(\mathrm{O}_{2}\right)$ and water [14] (Figure 1).

The hemoprotein family is a very interesting group of proteins for structureactivity relationship studies because the active center, iron porphyrin, is the same for all of the members, and the different activities arise from structural and conformational properties of the protein [15].

Most of the hemoprotein family members exhibit multiple types of activity. In 1994, Sun et al. pointed out that chloroperoxidase from Caldariomyces fumago (EC 1.11.1.10) had a catalase-like activity [16]. In 2001, Hernandez-Ruiz et al demonstrated the same phenomenon for the horseradish peroxidase (HRP; EC 1.11.1.7) [17]. On the other hand catalases also show peroxidase activities [18]. In 1979 , a new group of hemoprotein was discovered and named catalase-peroxidase (KatGs) [19]. KatGs are found in prokaryotes and fungi. They display a predominant catalase activity and a weak peroxidase activity with a broad specificity [20]. Nevertheless, on the basis of their primary sequence KatGs have been recognized to be part of the class I peroxidase super family [21]. All these elements tend to show that different hemoprotein activities may coexist, and is highly dependent on their tridimentional structure and on experimental conditions. 
Although the principal function of $\mathrm{Hb}$ is to transport oxygen, it has been shown that this protein has other functions [22], such as pseudo-enzymatic activities [23, 24, 25]. Oxyhemoglobin, in the presence of CYP reductase and the nicotinamide adenine dinucleotide phosphate (NADPH) cofactor, hydroxylates aromatic substrates such as aniline through a CYP-like oxygenase mechanism [26, 27, 28]. In the presence of $\mathrm{H}_{2} \mathrm{O}_{2}$, met-hemoglobin, can catalyze oxygenation of various substrates like 2,2'azino-bis(3-ethylbenzthiazoline-6-sulphonic acid (ABTS) and polycyclic aromatic hydrocarbons (PAH) through a peroxidase-like mechanism [29, 30, 31]. All these different activities of $\mathrm{Hb}$ are assumed to be the result of the heme ability to activate and react with oxygen species.

In the present paper, we report for the first time that $\mathrm{Hb}$, in addition of its oxygenase- and peroxidase-like activities, also presents a catalase-like activity. This oxygen-producing activity has been pointed out during the study of anthracene (ANT) oxidation through the peroxidase pathway of $\mathrm{Hb}$. Anthracene belongs to the PAH family which are carcinogenic and mutagenic pollutants found in waste waters from petroleum refineries as traces ( $\mathrm{ng}$ to $\mu \mathrm{g} / \mathrm{L}$ ) [32]. Bovine met-hemoglobin is a cheap material that comes from the food industry and is a very promising candidate for bioremediation of $\mathrm{PAH}$ in water. Here we present a detailed study of anthracene oxidation mechanism by met-hemoglobin and $\mathrm{H}_{2} \mathrm{O}_{2}$ revealing that in aqueous medium ANT oxidation is a "pseudo-catalytic" reaction. Furthermore, we show that to successfully remove $\mathrm{PAH}$ from water, care should be taken for high $\mathrm{Hb}$ and ANT concentrations low $\mathrm{H}_{2} \mathrm{O}_{2}$ concentrations otherwise the peroxidase activity of $\mathrm{Hb}$ is inhibited by its newly demonstrated catalase activity. Kinetic parameters and optimum $\mathrm{pH}$ have been determined for both anthracene oxidation (peroxidase activity) and oxygen production (catalase activity).

\section{Materials and methods}

\section{Chemicals}

Anthracene (ANT) and anthraquinone were purchased from Sigma-Aldrich (99\% purity), acetonitrile was of HPLC grade (SDS). Bovine met-hemoglobin (met$\mathrm{Hb}$ )was obtained from Sigma-Aldrich as a lyophilized powder (ref H2625). This $\mathrm{Hb}$ was used without any purification and considered as a pure preparation with a molecular weight of $64500 \mathrm{Da}$. The purity of the preparation has been checked using the SDS-page technique (12\% acrylamide) using standard protocol and coomassie blue staining. No traces of other protein has been detected. $\mathrm{H}_{2} \mathrm{O}_{2}$ was obtained as a $35 \%$ solution from Sigma-Aldrich. Chemicals for the buffers were reagent grade (Fluka). The ionic strength of the buffers was $0.05 \mathrm{M}$. For solutions of $\mathrm{pH}=3,4$ and 5 , a sodium citrate buffer was used $\left(\mathrm{C}_{6} \mathrm{H}_{8} \mathrm{O}_{7} / \mathrm{C}_{6} \mathrm{H}_{7} \mathrm{O}_{7} \mathrm{Na}\right)$. For buffers of $\mathrm{pH}=5.5,6,7$ and 8 , a phosphate buffer was used $\left(\mathrm{NaH}_{2} \mathrm{PO}_{4} / \mathrm{Na} 2 \mathrm{HPO}_{4}\right)$. All solutions were prepared using de-ionized water from a milli-Q purification system from Millipore.

\section{Anthracene oxidation study}


ANT oxidation studies were conducted in a $100 \mathrm{ml}$ reaction mixture containing from 0.3 to $15 \mu \mathrm{M} \mathrm{Hb}, 0.3$ to $3 \mu \mathrm{M}$ ANT , $1 \%$ acetonitrile $(\mathrm{v} / \mathrm{v})$ and $50 \mathrm{mM}$ phosphate buffer at $\mathrm{pH}=5$. ANT oxidation was started by adding various concentration of $\mathrm{H}_{2} \mathrm{O}_{2}$ (from 0.075 to $3 \mathrm{mM}$ ). The reaction progress was followed by ultrafast liquid chromatography (UFLC). ANT disappearance was calculated from the decreasing area of chromatogram peaks between reaction time $t=0$ and $t=x$. For initial rates determination, reactions were stopped at $t_{x}=5 \mathrm{~min}$ and the total disappearance measurement reactions were stopped at $t_{x}=15 \mathrm{~min}$. Reactions were performed in flasks protected by aluminum foil to avoid ANT photo-oxidation cross-reaction. To ensure reproducible results, after reaction and before UFLC analysis, samples have been dilute in $50 \%(\mathrm{v} / \mathrm{v})$ acetonitrile. The dilution step is necessary to stop the reaction and allows also a good stability to the samples before UFLC analysis. All reactions were repeated three times. Blanks without $\mathrm{H}_{2} \mathrm{O}_{2}$ and without $\mathrm{Hb}$ have also been realized. Oxidation products were identified by GC-MS after a continuous extraction of the media with $200 \mathrm{ml}$ of methylene chloride. The organic phase was dried with $\mathrm{Na}_{2} \mathrm{SO}_{4}$ and concentrated to $1 \mathrm{ml}$. Anthraquinone production has been quantified thanks to a calibration curve done with the commercial standard compound.

\section{UFLC analyses}

UFLC system used is a Shimadzu instrument, which was equipped with a Supelco reversed phase column C18-PAH (50 mm length $4.6 \mathrm{~mm}$ internal diameter and $3 \mu \mathrm{M}$ particles size). The chromatographic apparatus is composed of two pumps LC-20AD, an automatic sampler SIL-20AHT, a diode array detector SPD-M20A, a column oven CTO-20A, and a communication bus module CBM-20A.

Chromatograms were monitored with LabPower Shimadzu software. The separation method consists of a gradient between solvent $A(50 / 50(\mathrm{v} / \mathrm{v})$ water/acetonitrile) and solvent $B$ (acetonitrile) starting from $0 \%$ of $B$ over 0.5 minutes, then increasing $B$ up to $75 \%$ from 0.5 to 3 minutes, maintaining $75 \%$ of $B$ from 3 to 4.2 minutes, increasing $\mathrm{B}$ up to $100 \%$ from 4.2 to 4.5 and maintaining it to 5 minutes. Column oven is maintained at $40^{\circ} \mathrm{C}$ during the analysis. The retention time of ANT in this condition is $2.3 \mathrm{~min}$. Peak integration has been done with the maximum wave length adsorption of the compound $(251 \mathrm{~nm})$.

\section{GC-MS analyses}

GC-MS analyses were performed with a Shimadzu GC-2010 coupled to a Shimadzu MS-2010 and equipped with a Supelco SPB-5MS capillary column (30 m x $0,25 \mathrm{~mm})$. Ionization was carried out by electronic impact $(70 \mathrm{eV})$. The temperature of the ion source was $200{ }^{\circ} \mathrm{C}$ and the temperature interface was $280{ }^{\circ} \mathrm{C}$. The oven temperature program starts from $100^{\circ} \mathrm{C}$ during 5 minutes, then increasing $5{ }^{\circ} \mathrm{C} / \mathrm{min}$ to $280{ }^{\circ} \mathrm{C}$ and remaining at $280{ }^{\circ} \mathrm{C}$ for 11 minutes. $1 \mu \mathrm{l}$ of the extracted and concentrated sample was injected with a split equal to 10 and detection in the mass spectrometer was done in scan mode between 50 and $400(\mathrm{~m} / \mathrm{z})$. In these conditions, 
the retention times of anthracene and anthraquinone are 15 and 17 minutes respectively. Compound identification has been done with the NIST mass spectral database. The principal ion masses $(\mathrm{m} / \mathrm{z})$ for anthraquinone were $76,152,180,208$ and 178 for anthracene

\section{Oxygen production measurement}

Oxygen production measurement was performed with an oxygen electrode CellOx 325 coupled to an Inolab 730 oxymeter, both from WTW Company. The measurement was started by addition of $\mathrm{H}_{2} \mathrm{O}_{2}$ under soft stirring. The reaction volume was fixed at $100 \mathrm{ml}$. Oxygen production rates were measured in the first minute of the reaction. The effect of $\mathrm{pH}$ and of different $\mathrm{H}_{2} \mathrm{O}_{2}$ and $\mathrm{Hb}$ concentration has been studied. Reactions were repeated three times and blanks without $\mathrm{H}_{2} \mathrm{O}_{2}$ and without $\mathrm{Hb}$ have been performed.

\section{Kinetics parameters determination}

The kinetic parameters of the catalase-like activity and anthracene oxidation activity of $\mathrm{Hb}$ have been determined graphically by plotting experimental data obtained by measuring the initial rates of activity $(\mathrm{Vi})$ toward the substrates $\left(\mathrm{H}_{2} \mathrm{O}_{2}\right.$, ANT) concentration (S). The Lineweaver-Burk representation, $1 / \mathrm{Vi}=f(1 / \mathrm{S})$, allows the determination of the different kinetic parameters: Michaelis constant $\left(\mathrm{K}_{\mathrm{M}}\right)$, maximum rate activity $\left(\mathrm{V}_{\mathrm{m}}\right)$ and indirectly the catalytic constant $\left(\mathrm{k}_{\mathrm{cat}}\right)$.

\section{Results and discussion}

\section{Anthracene oxidation through the peroxidase activity of $\mathrm{Hb}$}

To determine optimal $\mathrm{pH}$ reaction conditions, the peroxidase activity of $\mathrm{Hb}$ $(0.15 \mu \mathrm{M})$ was measured between $\mathrm{pH}$ values of 3.0 and 8.0 in the presence of 150 $\mu \mathrm{M}$ of $\mathrm{H}_{2} \mathrm{O}_{2}$ and $0.3 \mu \mathrm{M}$ of ANT (Figure 2). The results show a narrow $\mathrm{pH}$ range for peroxidase activity, with an optimum $\mathrm{pH}$ value between 5.0 and 6.0. At a pH of 5.0, the maximum peroxidase activity corresponds to $76 \pm 5 \%$ of ANT elimination. At pH 4.0 and 7.0 , the remaining activity is less than $40 \%$ and $20 \%$ of the maximum activity, respectively. In the following studies, $\mathrm{pH}$ was maintained at 5.0.

In order to be as close as possible to waste water specificities, the challenge of the present work was to use very low co-solvent (acetonitrile) addition, $\sim 1 \%(\mathrm{v} / \mathrm{v})$, and low ANT concentration (0.3-3 $\mu \mathrm{M}$ ). Previously, Vazquez-Duhalt et al. had already noticed that the biocatalytic oxidation of $\mathrm{PAH}$ by $\mathrm{Hb}$ and $\mathrm{H}_{2} \mathrm{O}_{2}$ is strongly dependent on organic solvent concentration with an optimum of $15 \%(\mathrm{v} / \mathrm{v})$ acetonitrile [29]. According to this study, decreasing the acetonitrile concentration leads to a serious decrease of activity. For example, in 10\% (v/v) acetonitrile, the relative specific activity of $\mathrm{Hb}$ falls to $60 \%$. This may be due either to the fact that, for organic cosolvent concentrations below $10 \%$, the diffusion of $\mathrm{PAH}$ to the protein active site is slow, or that amount of co-solvent was not sufficient to dissolve the $\mathrm{PAH}$ in water since Vazquez-Duhalt et al. used an initial PAH concentration of $30 \mu \mathrm{M}$. It should be 
noted that this concentrations 100- to 1000-fold higher than the one present in waste water and which represents the goal of our study. As PAH compounds are very hydrophobic, they exhibit a low solubility in water. For example, the ANT solubility in pure water is $7.3 \mu \mathrm{M}$ [33]. Furthermore, $\mathrm{H}_{2} \mathrm{O}_{2}$ is a suicide substrate which inactivates the protein at the same time that it is used for the catalytic reaction [34]. One could think that, for low acetonitrile content, the inactivation of the protein is faster than the $\mathrm{PAH}$ oxidation because of a better $\mathrm{H}_{2} \mathrm{O}_{2}$ diffusion.

As a result, we show that total ANT disappearance, for a concentration in water of $0.3 \mu \mathrm{M}$ in a medium containing $1 \%(\mathrm{v} / \mathrm{v})$ acetonitrile, is possible if a stoichiometric amount or an excess of $\mathrm{Hb}$ with respect to ANT is used. Nearly total disappearance of ANT was reached when using a stoichiometric quantity or a twofold molar excess of $\mathrm{Hb}$ ( $94 \pm 5 \%$ and $97 \pm 5 \%$, respectively) (Figure $3 \mathrm{~A}$ ). Noteworthy, a very large molar excess of $\mathrm{H}_{2} \mathrm{O}_{2}$ was necessary to reach good levels of ANT oxidation. Indeed an excess of at least 1000, with respect to $\mathrm{Hb}$ concentration, was needed to reach $90 \%$ of ANT oxidation (Figure 3B). Anthracene oxidation, in these conditions, can be qualified of "pseudo-catalytic" because, even if $\mathrm{Hb}$ accelerates the reaction (allowing oxidation of ANT in the presence of $\mathrm{H}_{2} \mathrm{O}_{2}$ ), excesses of $\mathrm{Hb}$ and peroxide are required for a complete disappearance of ANT. One could think that the sub-stoichiometric behavior of the reaction limits the potential application of the process at an industrial scale but, as bovine met-Hb is a waste product from the food industry, it doesn't. In fact, abattoirs are an unlimited source of cheap bovine met-Hb. Moreover, the total disappearance of ANT under our conditions is reached in almost 15 minutes, which is much faster than usual catalytic process used to remove PAH. Methods such as oxidation catalyzed by porphyrin [35] or inorganic mineral oxide catalyst [36] with $\mathrm{H}_{2} \mathrm{O}_{2}$ or UV take at least several hours to reach their maximal efficiency.

Concerning ANT oxidation products, a small peak has been observed by the UFLC technique corresponding to $35 \%$ of the ANT that had disappeared. It was identified as anthraquinone by GC-MS The other remaining 65\% is supposed to be covalently linked to $\mathrm{Hb}$ as previously shown in the literature for other $\mathrm{PAHs}[37,38]$. In the present study, we use the term 'disappear' to qualify the reaction of $\mathrm{Hb}$ and $\mathrm{H}_{2} \mathrm{O}_{2}$ over ANT, because only a part of the disappearing substrate has been clearly identified as an oxidized product, and further studies should be necessary to determine exactly the state of ANT linked to the protein and its localization on the protein. This could be performed by using anthracene labeled by radioactive ${ }^{14} \mathrm{C}$ followed by the entire enzymatic digestion of the reacted hemoglobin to identify on which part of the hemoglobin the anthracene is attached, and also by analyzing oxidized PAH released after total hydrolysis of $\mathrm{Hb}$ as shown by Melikian et al [39]. Most probably the ANT is under a semi-oxidized form as no adsorption of ANT and anthraquinone onto the protein has been observed while running blank reactions without $\mathrm{H}_{2} \mathrm{O}_{2}$. Considering this fact, the term 'oxidation' can also be employed to qualify the reaction of ANT with $\mathrm{Hb}$ and $\mathrm{H}_{2} \mathrm{O}_{2}$ It should be noted that if the cross- 
linking of the ANT oxidation product to the protein is verified, it is also an advantage for an industrial process, because a major part of the oxidation product is trapped within the protein. If $\mathrm{Hb}$ is immobilized on a support, a recovery of the oxidized$\mathrm{HAP} /$ protein system is possible as well as its elimination by simple calcination process. Even if the oxidized forms of $\mathrm{PAH}$ are more biodegradable, they are also more carcinogenic [40] and as such, this global elimination process has to be considered.

In order to understand the mechanisms of ANT oxidation by $\mathrm{Hb}$ and to measure kinetic parameters, initial rates of the reaction $(\mathrm{Vi})$ have been assayed for different ANT concentrations $(0.3,0.6,1,2,3 \mu \mathrm{M})$, various $\mathrm{H}_{2} \mathrm{O}_{2}$ concentrations $(0.075,0.15,0.3,0.75$ and $1.5 \mathrm{mM})$ and fix $\mathrm{Hb}$ concentration $(1.5 \mu \mathrm{M})$. The Lineweaver-Burk representations, $1 / \mathrm{Vi}=\mathrm{f}(1 /[\mathrm{ANT}])$ and $1 / \mathrm{Vi}=\mathrm{f}\left(1 /\left[\mathrm{H}_{2} \mathrm{O}_{2}\right]\right.$ (Figure 4) show parallel lines for low ANT and high $\mathrm{H}_{2} \mathrm{O}_{2}$ concentration, which means that the oxidation of ANT by $\mathrm{Hb}$ fits a bi-bi ping-pong mechanism. This mechanistic model is typical of the peroxidase group [41,42]. First, $\mathrm{H}_{2} \mathrm{O}_{2}$ binds to the porphyrin iron to be activated, and then ANT reacts with the activated oxygen species. Nevertheless, for high ANT and low $\mathrm{H}_{2} \mathrm{O}_{2}$ concentrations, the lines are no longer parallel, showing a slowing of the ANT disappearance rates. It is not easy to observe in Figure 4 because rates are very close to one another, due to the tight differences between the various ANT concentrations studied, but for $\mathrm{H}_{2} \mathrm{O}_{2} \leq 0.15 \mathrm{mM}$ and ANT $\geq 2 \mu \mathrm{M}$ the rates of reaction decrease.

Kinetic parameters determined for anthracene oxidation were $\mathrm{V}_{\max }=0.25 \pm$ $0.01 \mu \mathrm{M} / \mathrm{min}, \mathrm{K}_{\mathrm{M}(\mathrm{H} 2 \mathrm{O} 2)}=80 \mu \mathrm{M}, \mathrm{K}_{\mathrm{M}(\mathrm{ANT})}=1.1 \mu \mathrm{M}$ and $\mathrm{k}_{\text {cat }}=0.170 \pm 0.005 \mathrm{~min}^{-1}$. The very tight $\mathrm{Km}$ for anthracene is surprising, but it should be noted that it has not been determined under saturation conditions. Indeed due to its poor solubility in an aqueous medium, the maximum concentration of anthracene was $3 \mu \mathrm{M}$ far below $\mathrm{Hb}$ saturation $([\mathrm{Hb}]=1.5 \mu \mathrm{M})$. Moreover, the $\mathrm{Hb}$ concentrations required to accurately measure oxidation rates should be high compared to the ANT concentrations. Thus, it was not feasible to work with an excess of anthracene in a medium containing only $1 \%(\mathrm{v} / \mathrm{v})$ of acetonitrile. Nevertheless, our data shows that the system works almost as if it was saturated with anthracene. Indeed, with saturating $\mathrm{H}_{2} \mathrm{O}_{2}$ concentrations, the initial rates over $1 \mu \mathrm{M}$ ANT, increased just slightly (Figure 4). Considering this fact, our results showed that the reaction was slow $\left(\mathrm{V}_{\max }=0.25 \pm 0.01 \mu \mathrm{M} / \mathrm{min}\right)$ but it was compensated by the good affinity of ANT for $\mathrm{Hb}\left(\mathrm{K}_{\mathrm{M}(\mathrm{ANT})}=1.1 \mu \mathrm{M}\right)$. The observed rate $\left(0.17 \mathrm{~min}^{-1}\right)$, in our study, is below the reported rate $\left(0.4 \mathrm{~min}^{-1}\right)$ in the previous work done by Vazquez-Duhalt et al in 1995 and 2000 [29, 31]. Firstly, this difference can be explained by the co-solvent concentration. In our study, $1 \%$ acetonitrile was used in contrast to $15 \%$ in the Vazquez-Duhalt work. More acetonitrile in the media can increase the ANT solubility with an impact on the kinetic parameters. On the other hand, Vazquez-Duhalt et al worked with human $\mathrm{Hb}$ which can have a slight different reactivity. But even if both proteins react in exactly the same way, the purification process to obtain the proteins can vary and bovine met- 
$\mathrm{Hb}$, even if it is as pure as human $\mathrm{Hb}$, can be less active. Whatever it is, our approach is more suited to a possible industrial waste water biotechnological treatment process because of the reactions conditions (low co-solvent and PAH concentrations) and because bovine met- $\mathrm{Hb}$ is surely more suitable than human $\mathrm{Hb}$ for a biotechnological process.

Working with a fixed and low $\mathrm{H}_{2} \mathrm{O}_{2}$ concentration $(150 \mu \mathrm{M})$, variable $\mathrm{Hb}$ concentrations $(0.15,0.3,1.5,3,15 \mu \mathrm{M})$ and high anthracene concentration $(3 \mu \mathrm{M})$ (Figure 5), in the zone where ANT oxidation rates were slow down (Figure 4), showed that this inhibition is not due to a typical substrate excess inhibition. On one hand, $\mathrm{Hb}$ peroxidase relative activity, (in terms of total anthracene disappearance) increased from 63 to $100 \%$ between 0.2 and $1.5 \mu \mathrm{M} \mathrm{Hb}$. On the other hand, the same relative activity falls down from 100 to $58 \%$ between 1.5 and $15 \mu \mathrm{M} \mathrm{Hb}$. To summarize, considering results from the graph 4-A and $\mathrm{B}$, discussed above, the inhibition of ANT oxidation takes place for $[\mathrm{Hb}] /\left[\mathrm{H}_{2} \mathrm{O}_{2}\right] \leq 100$ and $\left[\mathrm{H}_{2} \mathrm{O}_{2}\right] /[\mathrm{ANT}] \leq 75$. These results define an inhibition zone which should be taken into account for a likely industrial application for PAH removal in aqueous media. Nevertheless, most of the time, reaction conditions are outside of this inhibition zone because a large excess of peroxide compared to $\mathrm{Hb}$ is used and the $\mathrm{PAH}$ concentration in waste water is very low $(\mathrm{nM})$.

These results suggested that $\mathrm{H}_{2} \mathrm{O}_{2}$ was consumed through an alternative pathway. Additionally, for $[\mathrm{Hb}]=15 \mu \mathrm{M}$ and $\left[\mathrm{H}_{2} \mathrm{O}_{2}\right]=15 \mathrm{mM}$, small gas bubbles appeared and foam was forming. This observation strongly suggested that $\mathrm{Hb}$ produced a gas from $\mathrm{H}_{2} \mathrm{O}_{2}$. The sole gas that could potentially be produced by hemoproteins is $\mathrm{O}_{2}$, coming from the dismutation of $\mathrm{H}_{2} \mathrm{O}_{2}$ through a catalase-like mechanism. During this type of activity $\mathrm{H}_{2} \mathrm{O}_{2}$ plays both an oxidative and a reductive role to form molecular oxygen [14] (Figure 1). Nevertheless, this reaction has never been observed for $\mathrm{Hb}$.

\section{Catalase-like activity of $\mathrm{Hb}$}

In order to study the potential catalase-like activity of $\mathrm{Hb}$ and to ensure reliable results, following experiments have been performed in absence of ANT. A high concentration of $\mathrm{H}_{2} \mathrm{O}_{2}$ was used in order to have significant $\mathrm{O}_{2}$ production rates. $\mathrm{O}_{2}$ emission was measured by oxymetry.

Firstly, optimal $\mathrm{pH}$ reaction condition was determined by measuring the catalase activity between $\mathrm{pH}=3.0$ and 8.0 with $\mathrm{Hb} 3 \mu \mathrm{M}$ in the presence of $5 \mathrm{mM}$ $\mathrm{H}_{2} \mathrm{O}_{2}$ (Figure 2). Results show a wide $\mathrm{pH}$ range for $\mathrm{O}_{2}$ emission. The optimum $\mathrm{pH}$ activity is between $5.0<\mathrm{pH}<7.0$, but even at $\mathrm{pH}=8.0$, more than $50 \%$ of $\mathrm{Hb}$ catalase-like activity remains. The catalase activity of $\mathrm{Hb}$ is less sensitive to $\mathrm{pH}$ compared to its peroxidase activity. It should be noted that at a pH of 8 , only the 
catalase activity occurs, but there is no $\mathrm{pH}$ value at which one can work with only the peroxidase activity of bovine met- $\mathrm{Hb}$. The following experiments were run at $\mathrm{pH}=$ 6.0 .

For $\left[\mathrm{H}_{2} \mathrm{O}_{2}\right]=1.5 \mathrm{mM}$, increasing the $\mathrm{Hb}$ concentrations $(1.5,3,15,30 \mu \mathrm{M})$ led to an effective production of $\mathrm{O}_{2}$ with regards to $\mathrm{Hb}$ concentration. Whereas the solubility of $\mathrm{O}_{2}$ in water is only $8 \mathrm{mg} / \mathrm{l}$, an emission of $22 \mathrm{mg}$ of $\mathrm{O}_{2}$ per liter has been measured in 10 minutes with $[\mathrm{Hb}]=30 \mu \mathrm{M}$ (Figure 6). The $\mathrm{O}_{2}$ production rates evolved linearly $\left(r^{2}=0.9971\right.$, Figure 6$)$ clearly demonstrating the catalytic nature of this catalase-like activity. Initial $\mathrm{O}_{2}$ production rates have been determined for $\left[\mathrm{H}_{2} \mathrm{O}_{2}\right]$ $=5 \mathrm{mM}$ and various $\mathrm{Hb}$ concentrations $(1.5,3,5,7.5,10,12.5,15 \mu \mathrm{M})$. For a fixed $\mathrm{H}_{2} \mathrm{O}_{2}$ concentration, more hemoglobin gives more oxygen production.

The Lineweaver-Burk representation of $\mathrm{O}_{2}$ production (Figure 7), measured at a fix $\mathrm{Hb}$ concentration $(3 \mu \mathrm{M})$ versus increasing $\mathrm{H}_{2} \mathrm{O}_{2}$ concentrations $(1,5,10,25,50$ $\mathrm{mM})$, allowed us to determine the kinetic constants of $\mathrm{Hb}$ catalase-like activity.

Results give $\mathrm{V}_{\max }=344 \pm 24 \mu \mathrm{M} / \mathrm{min}, \mathrm{K}_{\mathrm{M}}=24.4 \pm 5.2 \mathrm{mM}$ and $\mathrm{k}_{\text {cat }}=115 \pm 8 \mathrm{~min}^{-1}$. It shows that $\mathrm{Hb}$ catalase-like activity is fast but the affinity of $\mathrm{H}_{2} \mathrm{O}_{2}$ for $\mathrm{Hb}$ is weak. In term of comparison, Hernandez-Ruiz et al. have calculated the catalytic parameters for the catalase-like activity of horseradish Peroxidase and found: $K_{M}=4 \mathrm{mM}$ and $\mathrm{k}_{\text {cat }}$ $=110 \mathrm{~min}^{-1}[17]$. The kinetic parameters of the catalase-like activity of chloroperoxidase from $C$. fumago measured by Sun et al. are $\mathrm{K}_{M}=3.3 \mathrm{mM}$ and $\mathrm{k}_{\text {cat }}=$ $54000 \mathrm{~min}^{-1}$ [16]. The catalase activity of $\mathrm{Hb}$ is faster but in the same range of order of HRP, but much slower than chloroperoxidase. However, the affinity of $\mathrm{H}_{2} \mathrm{O}_{2}$ is less for $\mathrm{Hb}$ than for HRP and chloroperoxidase, which are equal to each other.

An explanation for this catalase activity could be the presence of a contaminating catalase in the met-hemoglobin preparation. However this hypothesis can be easily contradicted since the kinetic parameters of $\mathrm{Hb}$ catalase activity are very different from those found for real catalases, such as catalase from Micrococcus lysodeikticus [43, 44], featuring a $\mathrm{K}_{\mathrm{M}}$ of $1100 \mathrm{mM}$ for $\mathrm{H}_{2} \mathrm{O}_{2}$, which is almost 46-fold higher than the one calculated for $\mathrm{Hb}(25 \mathrm{mM})$. Additionally, the $\mathrm{Hb}$ catalase activity presents a saturation kinetic under steady-state conditions, which is not the case of the bacterial catalase (Figure 7). These kinetic elements are sufficient to show that $\mathrm{Hb}$ preparation is not contaminated by catalase. Two different batches of $\mathrm{Hb}$ were used with two commercial purities (Sigma-Aldrich ref 2625 and ref 2500), and the same catalase activity was noticed. Moreover, a sodium dodecyl sulfate polyacrylamide gel electrophoresis has been performed with $\mathrm{Hb}$ and no traces of other proteins could be detected, showing that this activity doesn't come from some contaminating residual enzymatic activity (Figure 8). Nevertheless, as this hemoglobin catalase-like activity has never been described before, it should be verified, in further studies, if it is only in the case of bovine met-Hb or if it also exists for human and other $\mathrm{Hb}$ proteins.

The $\mathrm{Hb}$ catalase activity described here can be defined as a promiscuous catalytic activity [45] since it is a side reaction catalyzed by the wild-type $\mathrm{Hb}$ which is distinctly different from the main function known for $\mathrm{Hb}$. This "promiscuous" property 


\section{Concluding remarks}

The ANT oxidation by the peroxidase-like activity of hemoglobin proceeds through a bi-bi ping-pong mechanism. In aqueous medium, anthracene oxidation rates and turnover numbers are very low, probably due to the limited diffusion of anthracene to the active site of hemoglobin. It can be qualified as a pseudo-catalytic system. In aqueous media, total disappearance of anthracene traces can be performed within 15 minutes but with high amount of $\mathrm{Hb}$. This requirement does not prohibit industrial applications because bovine met- $\mathrm{Hb}$ is a waste from food industry with a low production cost.

Bovine met-Hb presents a catalase-like activity described here for the first time. This activity interfered with the peroxidase-like activity especially for $[\mathrm{Hb}] /\left[\mathrm{H}_{2} \mathrm{O}_{2}\right]$ $\leq 100$ and $\left[\mathrm{H}_{2} \mathrm{O}_{2}\right] /[\mathrm{ANT}] \leq 75$. 
Thus, hemoglobin is a good example of accidental catalytic promiscuity as recently defined [44]. Despite its principal role is to transport oxygen, it also possesses low peroxidase-, oxygenase- and catalase-like activities.

\section{Acknowledgment}

The authors are grateful for the financial support from the TOTAL France S.A company and to Naseem Ramsahye for the English revision of the manuscript. 
[1] Perutz, M. F., Hemoglobin structure and respiratory transport,Sci. Am. 1978, 239 (6), 92-125.

[2] Wallace, W. J., Houtchens, R. A., Maxwell, J. C., Caughey, W. S., Mechanism of autooxidation for hemoglobins and myoglobins. Promotion of superoxide production by protons and anions, J. Biol. Chem. 1982, 257 (9), 4966-4977.

[3] Marden, M. C., Griffon, N., Poyart, C., Oxygen delivery and autoxidation of hemoglobin, Transfus. Clin. Biol. 1995, 2 (6), 473-80.

[4] Castro, C. E., Mechanisms of reaction of hemeproteins with oxygen and hydrogen peroxide in the oxidation of organic substrates, Pharmacol. Ther. 1980, 10, 171-189

[5] Bathelt, C. M., Ridder, L., Mulholland, A. J., Harvey, J. N., Aromatic hydroxylation by cytochrome P450: model calculations of mechanism and substituent effects, J. Am. Chem. Soc. 2003, 125 (49), 15004-15005

[6] Bugg, T. D. H., Oxygenases: mechanisms and structural motifs for $\mathrm{O} 2$ activation, Cur. Opin Chem. Biol. 2001, 5 (5), 550-555

[7] England, P. A., Harford-Cross, C. F., Stevenson, J-A., Rouch, D. A., et al., The oxidation of naphthalene and pyrene by cytochrome P450cam FEBS, Lett. 1998, 424, 271-274.

[8] Günther, T., Sack, U., Hofrichter M., Lätz M., Oxidation of PAH and PAH-derivatives by fungal and plant oxidoreductases, J. Basic Microbiol. 1998, 38, 113-122.

[9] Carmichael, R., Fedorak, P. M., Pickard, M. A., Oxidation of phenols by chloroperoxidase, Biotechnol. Lett. 1985, 7 (4), 289-294.

[10]Davidenko, T. I., Oseychuk, O. V., Sevastyanov, O. V., Romanovskaya, I. I., Peroxidase Oxidation of Phenols, Appl. Biochem. Microbiol. 2004, 40 (6), 542-546.

[11]van Deurzen, M. P. J., van Rantwijk, F., Sheldon, R. A., Selective oxidations catalyzed by peroxidases, Tetrahedron 1997, 53 (39), 13183-13220.

[12]Vazquez-Duhalt, R., Ayala, M., Marquez-Rocha, F. J., Biocatalytic chlorination of aromatic hydrocarbons by chloroperoxidase of Caldariomyces fumago, Phytochem. 2001, 58, 929-933.

[13]Regalado, C., Garcia-Almendarez, B. E., Duarte-Vazquez, M. A., Biotechnological applications of peroxidases, Phytochem. 2004, 3, 243-256

[14]Hersleth, H-P., Ryde, U., Rydberg, P., Görbitz, C. H., et al., Structures of the high-valent metal-ion haem-oxygen intermediates in peroxidases, oxygenases and catalases, J. Inorg. Biochem. 2006, 100, 460-476.

[15]Ortiz de Montellano, P. R., Arylhydrazines as probes of hemoprotein structure and function, Biochimie 1995, 77 (7-8), 581-593.

[16]Sun, W., Kadima, T. A., Pickard, M. A., Dunford, H. B., Catalase activity of chloroperoxidase and its interaction with peroxidase activity, Biochem. Cell. Biol. 1994, 72, 321-331.

[17]Hernandez-Ruiz, J., Arnao M. B., Hiner, A. N. P., Garcia-Canovas, F., et al., Catalase-like activity of horseradish peroxidase: relationship to enzyme inactivation by $\mathrm{H}_{2} \mathrm{O}_{2}$, Biochem. J. 2001, 354, 107114.

[18]Sichak, S. P., Dounce, A. L., Analysis of the peroxidatic mode of action of catalase, Arch. Biochem. Biophys. 1986, 249 (2), 286-295.

[19]Brown-Peterson, N. J., Salin, M. L., Purification of a catalase-peroxidase from Halobacterium halobium: characterization of some unique properties of the halophilic enzyme, J. Bacteriol. 1993, 175 (13), 4197-4202.

[20]Singh, R. , Wiseman, B. , Deemagarn, T., Jha, V., et al., Comparative study of catalaseperoxidases (KatGs), Arch. Biochem. Biophys. 2007, 471 (2), 207-214.

[21]Welinder, K.G., Bacterial catalase-peroxidases are gene duplicated members of the plant peroxidase superfamilly, Biochim. Biophys .Acta. 1991, 1080 (3), 215-20.

[22]Giardina, B., Messana, I., Scatena, R., Castagnola, M., The multiple functions of hemoglobin, Crit. Rev. Biochem. Mol. Biol. 1995, 30 (3), 165-196.

[23] Carrell, R. W., Winterbourn, C. C., French, J. K., Hemoglobin - a Frustrated Oxidase? Implication for Red Cell Metabolism, Hemoglobin 1977, 1 (8), 815-927.

[24]Mieyal, J. J., Ackerman, R. S., Blumers, J. L., Freeman, L. S., Characterization of Enzyme-like activity of human hemoglobin. Properties of the hemoglobin-P-450 reductase-coupled aniline hydroxylase system, J. Biol. Chem. 1976, 251, 3436-3441. 
[25]Elbaum, D., Nagel, R. L., Esterase activity of hemoglobin. Differences between HB A and HB S, J. Biol. Chem. 1981, 256 (5), 2280-2283.

[26]Cambou, B., Guillochon, D., Thomas, D., Aniline hydroxylase activities of haemoglobin: kinetics and mechanism, Enzyme Microb. Technol. 1984, 6, 11-17.

[27]Esclade, L., Guillochon, D., Thomas, D., Aromatic hydroxylations in peroxidations by haemoglobin systems, Xenobiotica, 1986, 16 (7), 615-624.

[28]Chapsal, J. M., Bourbigot, M. M., Thomas, D., Oxidation of aromatic compounds by haemoglobin, Water Res. 1986, 20 (6), 709-713.

[29]Ortiz-Leon, M., Velasco, L., Vazquez-Duhalt, R., Biocatalytic oxidation of polycyclic aromatic hydrocarbons by hemoglobin and hydrogen peroxide., Biochem. Biophys. Res Commun. 1995, 215 (3), 968-973.

[30]Stachyra, T., Guillochon, D., Pulvin, S., Thomas, D., Hemoglobin, horseradish peroxidase, and heme-bovine serum albumin as biocatalyst for the oxidation of dibenzothiophene, Appl. Biochem. Biotechnol., 1996, 59 (3), 231-243

[31] Torres, E., Vazquez-Duhalt, R., Chemical Modification of Hemoglobin Improves Biocatalytic Oxidation of PHAs, Biochem. Biophys. Res Commun. 2000, 273, 820-823.

[32]Randerath, K., Randerath, E., Zhou, G.D., Supunpong, N., et al., Genotoxicity of complex PAH mixtures recovered from contaminated lake sediments as assessed by three different methods, Environ Mol Mutagen 1999, 33 (4), 303-312.

[33]Bisson, M., Heuze, G., Lacroix, G., Lefevre, J.P., Magaud, H., Malleret, L., Anthracène, INERIS Fiche de données toxicologiques et environnementales des substances chimique, 2005

[34]Arnao, M. B., Acosta, M., del Rio, J.A., Varon, R., et al., Reactions of the Class II Peroxidases, Lignin Peroxidase and Arthromyces ramosus Peroxidase, with Hydrogen Peroxide. Catalase-like activity, compound III formation, and enzyme inactivation, Biochem. Biophys. Acta. 1990 1041, 43-47. [35]Giri, N. G.; Chauhan, S. M. S., Oxidation of polycyclic aromatic hydrocarbons with hydrogen peroxide catalyzed by Iron(III)porphyrins, Catal Commun 2009, 10, (4), 383-387.

[36] Garcıa-Martınez, M.J., Canoira, L., Blazquez, G., Da Riva, I., et al., Continuous photodegradation of naphthalene in water catalyzed by TiO2 supported on glass Raschig rings, Chem. Eng. J. 110 (2005) 123-128

[37]Sugihara, N., James, M. O., Binding of 3-hydroxybenzo[a]pyrene to bovine hemoglobin and albumin, J. Biochem. Mol. Toxicol. 2003, 17 (4), 239-247.

[38]Waidyanatha, S., Rappaport, S. M., Hemoglobin and albumin adducts of naphthalene-1,2oxide,1,2-naphthoquinone and 1,4-naphthoquinonein Swiss Webster mice, Chem. Biol. Interact., 2008 172, 105-114

[39] Melikian, A. A., Sun, P., Pierpont, C., Coleman, S., Hecht, S. S., Gas chromatographic-mass spectrometric determination of benzo[a]pyrene and chrysene diol epoxide globin adducts in humans Cancer Epidemiol Biomarkers Prev 1997, 6, 833-839.

[40]Cavalieri, E. L., Rogan, E. G., Radical cations in aromatic hydrocarbon carcinogenesis, Free Radical Res., 1990, 11, (1), 77 - 87.

[41]Kedderis, G. L., Hollenberg, P. F., Steady state kinetics of chloroperoxidase-catalyzed Ndemethylation reactions, J. Biol. Chem. 1983, 258 (20), 12413-12419.

[42]Choi, Y-J., Chae, H. J., Kim, E. Y., Steady-State Oxidation Model by Horseradish Peroxidase for the Estimation of the Non-Inactivation Zone in the Enzymatic Removal of Pentachlorophenol., J. Biosci. Bioeng. 1999, 88 (4), 368-373.

[43]Ogura, Y., Catalase activity at high concentration of hydrogen peroxide, Arch. Biochem. Biophys. 1955, 57, 288-300

[44]Jones P., Suggett A., The catalase-hydrogen peroxide system. Kinetics of catalatic action at high substrate concentrations, Biochem. J. 1968, 110 (4), 617-620.

[45]Hult, K., Berglund, P., Enzyme promiscuity: mechanism and applications, Trends Biotechnol. 2007, $25,231-238$

[46]Afriat, L., Roodveldt, C., Manco, G., Tawfik, D. S., The latent promiscuity of newly identified microbial lactonases is linked to a recently diverged phosphotriesterase, Biochemistry 2006, 45 (46), 13677-13686

[47]Jensen, R. A., Enzyme recruitment in the evolution of new function, Annu. Rev. Microbiol. 1976, 30 (1), 409-425.

[48]Zamocky, M., Janecek, S., Koller, F., Common phylogeny of catalase-peroxidases and ascorbate peroxidases, Gene 2000, 256, 169-182. 


\section{Figures legend:}

Figure 1. Catalytic cycles of hemoproteins (the square is representing the heme group): 1- CYP Monooxygenation cycle: the insertion of one atom of oxygen into a substrate $\mathrm{RH}$ from molecular oxygen with the concomitant release of water through a complex pathway needing electrons and protons transfer before obtaining the active compound $\mathrm{Fe}^{\mathrm{IV}}=\mathrm{O}^{++}$which reacts with $\mathrm{RH}$ to gives $\mathrm{ROH}$ (this pathway can be quenched by the presence of carbon monoxide); 2- In the peroxidase pathway, $\mathrm{H}_{2} \mathrm{O}_{2}$ oxidizes directly $\mathrm{Fe}$ III into the active compound $\mathrm{Fe}^{\mathrm{IV}}=\mathrm{O}^{++}$which then reacts with $\mathrm{RH}$; 3- $\mathrm{The}$ catalase pathway: the active compound $\mathrm{Fe}^{\mathrm{IV}}=\mathrm{O}^{+}$, formed by the action of a first $\mathrm{H}_{2} \mathrm{O}_{2}$ molecule, can react with a second $\mathrm{H}_{2} \mathrm{O}_{2}$ molecule and lead to the release of $\mathrm{O}_{2}$ and $\mathrm{H}_{2} \mathrm{O}$.

Figure 2. Relative hemoglobin pseudo-peroxidase and catalase activity versus pH. For peroxidaselike activity, the initial anthracene concentration was $0.3 \mu \mathrm{M}, 1 \%$ acetonitrile $(\mathrm{v} / \mathrm{v}),\left[\mathrm{H}_{2} \mathrm{O}_{2}\right]=150 \mu \mathrm{M}$ and $[\mathrm{Hb}]=0.15 \mu \mathrm{M}$. The maximum activity, in terms of total ANT disappearance, was $76 \pm 5 \%$ at $\mathrm{pH}=5$. Analyses were done after complete reaction (15 minutes) by UFLC. For catalase-like activity, $[\mathrm{Hb}]=3 \mu \mathrm{M},\left[\mathrm{H}_{2} \mathrm{O}_{2}\right]=5 \mathrm{mM}$. Analyses were done with an oxymeter during the first minutes after addition of $\mathrm{H}_{2} \mathrm{O}_{2}$. The maximum activity, in terms of initial $\mathrm{O}_{2}$ production rate, was $62 \mu \mathrm{M} / \mathrm{min}$ at $\mathrm{pH}=6$.

Figure 3. A : Total anthracene disappearance versus hemoglobin concentration. The initial anthracene concentration was $0.3 \mu \mathrm{M}$ in phosphate buffer $50 \mathrm{mM}, \mathrm{pH}=5,1 \%$ acetonitrile $(\mathrm{v} / \mathrm{v})$. A molar excess $\left[\mathrm{H}_{2} \mathrm{O}_{2}\right] /[\mathrm{Hb}]=1000$ was used for all reactions. Analyses were made after complete reaction (15 minutes) by UFLC. B: Relative activity of $\mathrm{Hb}$ on ANT elimination at variable $\left[\mathrm{H}_{2} \mathrm{O}_{2}\right] /[\mathrm{Hb}]$ ratios. The initial anthracene concentration was $0.3 \mu \mathrm{M}$ in phosphate buffer $50 \mathrm{mM}, \mathrm{pH}=5,1 \%$ acetonitrile $(\mathrm{v} / \mathrm{v})$. $\mathrm{Hb}$ concentration was $0.15 \mu \mathrm{M}$. Maximum activity, in terms of total ANT disappearance was $85 \pm 5 \%$ for $\left[\mathrm{H}_{2} \mathrm{O}_{2}\right] /[\mathrm{Hb}]=5$ 000. Analyses were made after complete reaction (15 minutes) by UFLC

Figure 4. Lineweaver-Burk plot of initial anthracene disappearance rates, at variable $\mathrm{H}_{2} \mathrm{O}_{2}$ concentration $(A)$ and at various anthracene concentrations (B). Reactions were conducted in phosphate buffer $50 \mathrm{mM} \mathrm{pH}=5$, with different $\mathrm{H}_{2} \mathrm{O}_{2}$ concentrations $(0.075,0.15,0.3,0.75,1.5 \mathrm{mM})$, various ANT concentrations $(0.3,0.6,1,2,3 \mu \mathrm{M})$ and a fixed $\mathrm{Hb}$ concentration $(1.5 \mu \mathrm{M})$. Analyses were done after 5 minutes reaction by UFLC.

Figure 5. Relative peroxidase-like activity of $\mathrm{Hb}$ on anthracene oxidation at low $\mathrm{H}_{2} \mathrm{O}_{2}$ concentration $(150 \mu \mathrm{M})$ in function of $\mathrm{Hb}$ concentrations. Reactions were done in phosphate buffer $50 \mathrm{mM}, \mathrm{pH}=5$, $[\mathrm{ANT}]=3 \mu \mathrm{M}$. The maximum activity, in term of total disappearance, was $57 \pm 5 \%$ with $[\mathrm{Hb}]=1.5 \mu \mathrm{M}$. Analyses were done after complete reaction ( $15 \mathrm{~min}$ ) by UFLC 
Figure 6. $\mathrm{A}: \mathrm{O}_{2}$ emission $(\mathrm{mg} / \mathrm{L})$ for $\left[\mathrm{H}_{2} \mathrm{O}_{2}\right]=1.5 \mathrm{mM}$ and various $\mathrm{Hb}$ concentration $(0,1.5,3,15,30$ $\mu \mathrm{M})$. Measurements were done with an oxymeter. B: Linear initial $\mathrm{O}_{2}$ production rates in function of $\mathrm{Hb}$ concentration $(1.5,3,5,7.5,10,12.5,15 \mu \mathrm{M}) . \mathrm{H}_{2} \mathrm{O}_{2}$ concentration was kept fixed for all reactions (5 $\mathrm{mM}$ ). Reactions were done in a phosphate buffer $50 \mathrm{mM}, \mathrm{pH}=6$. Measurements were done with an oxymeter in the first minutes after $\mathrm{H}_{2} \mathrm{O}_{2}$ addition.

Figure 7. A: Initial $\mathrm{O}_{2}$ production rates by $\mathrm{Hb}$ in function of $\left[\mathrm{H}_{2} \mathrm{O}_{2}\right]$ showing the saturation kinetic of $\mathrm{Hb}$ catalase activity. Reactions were done in phosphate buffer $50 \mathrm{mM}, \mathrm{pH}=6,[\mathrm{Hb}]=3 \mu \mathrm{M}$. Measurements were done with an oxymeter during the first minutes after $\mathrm{H}_{2} \mathrm{O}_{2}$ addition. $\mathrm{B}$ : Lineweaver-Burk plot of initial $\mathrm{O}_{2}$ production rates.

Figure 8. SDS-page gel photo. Left: standards with various molecular weights. Phosphorylase b $(97400 \mathrm{Da})$, bovine serum albumin $(66200 \mathrm{Da})$, ovalbumin $(45000 \mathrm{Da})$, carbonic anhydrase $(31000$ Da), soybean trypsin inhibitor (21500 Da) and lysozyme (14400 Da). Right: Hb (10g/L). 
Fig 1

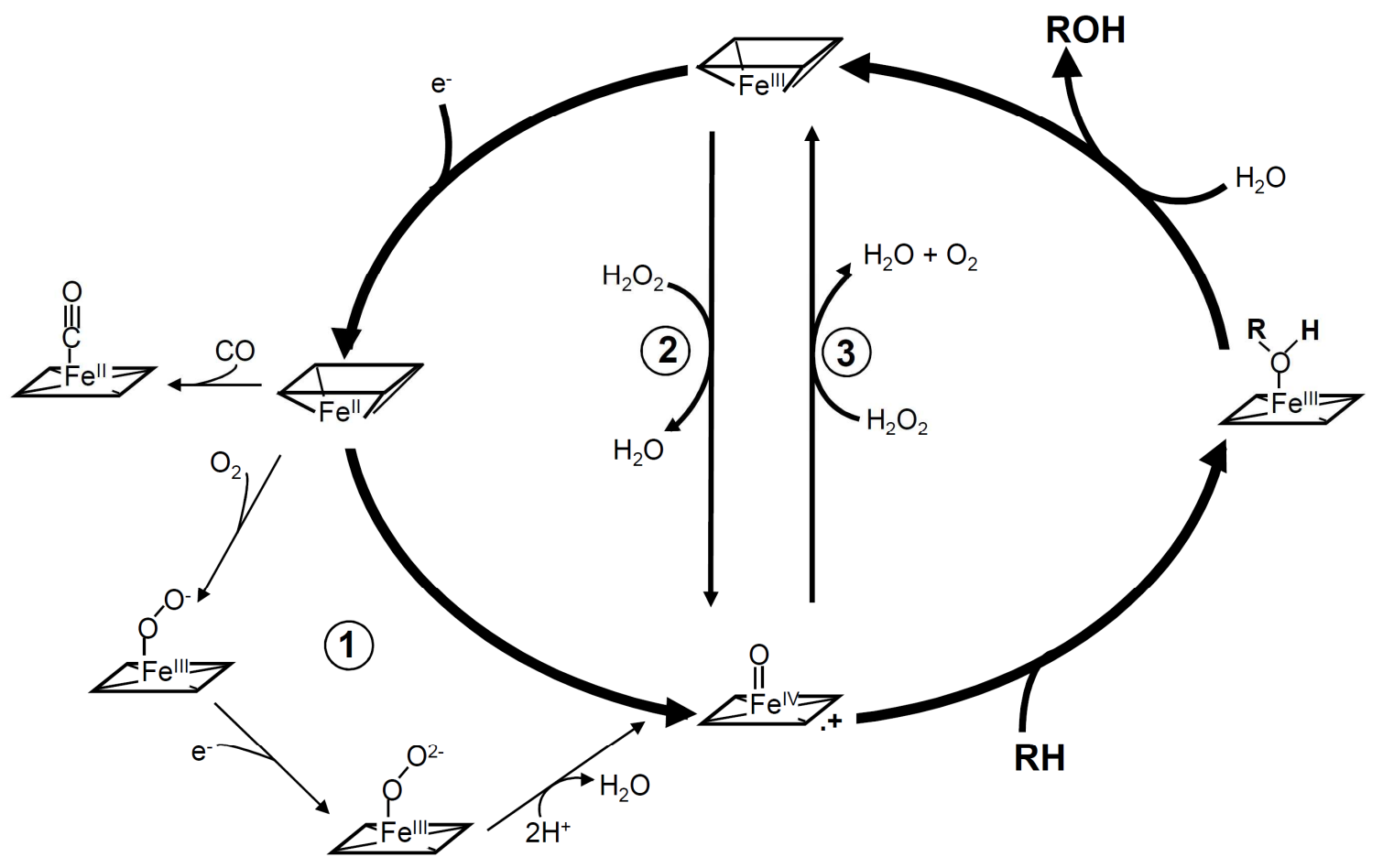


Fig 2

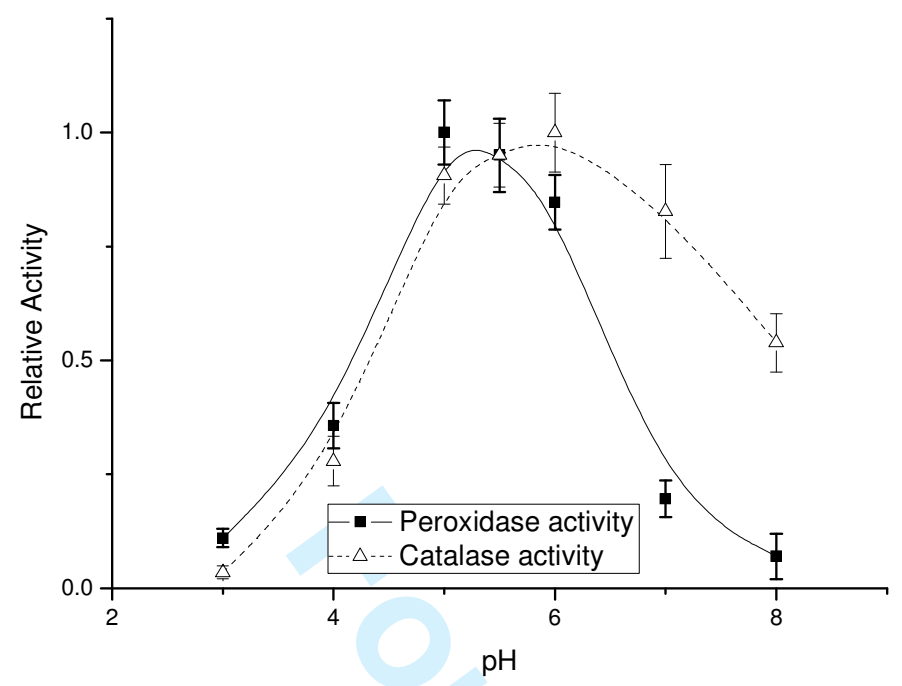


1

2

3

4

5

6

7

8

9

10
11

12

13

14

15

16

17

18

19

20

21

22

23

24

25

26

27

28

29

30

31

32

33

34

35

36

37

38

39

40

41

42

43

44

45

46

47

48

49

50

51

52

53

54

55

56

57

58

59

60

Fig $3 \mathrm{~A}$ and $\mathrm{B}$
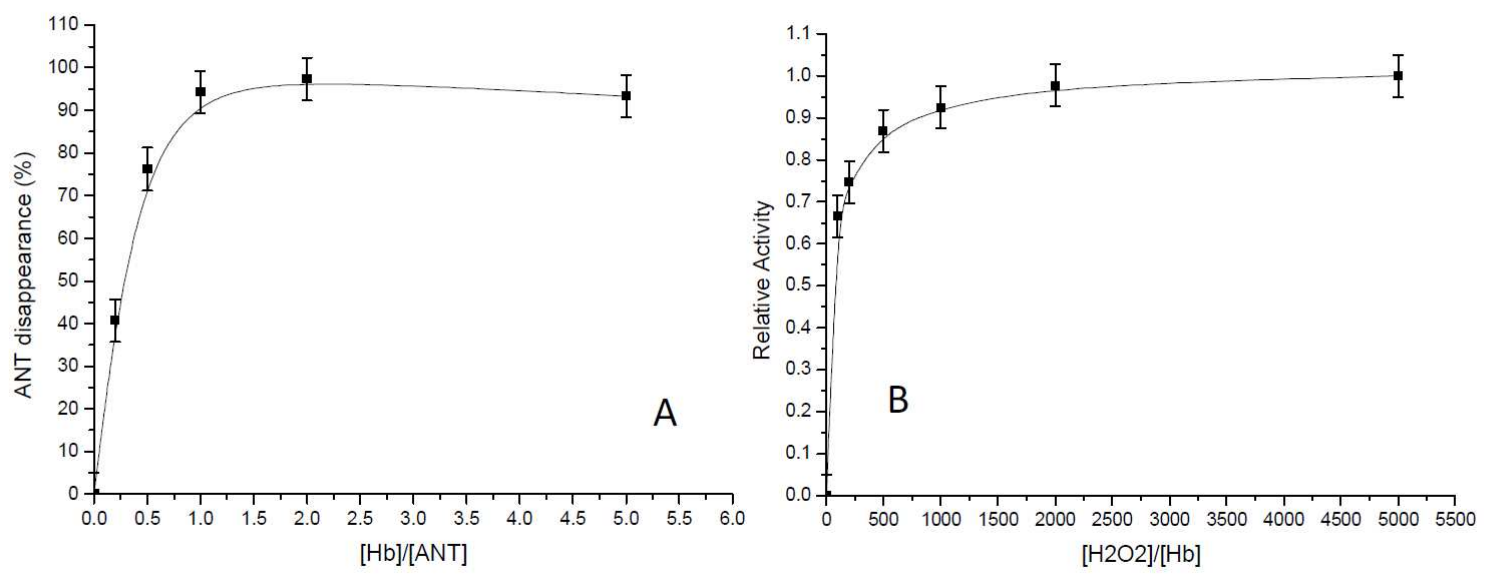
Fig $4 \mathrm{~A}$ and $\mathrm{B}$
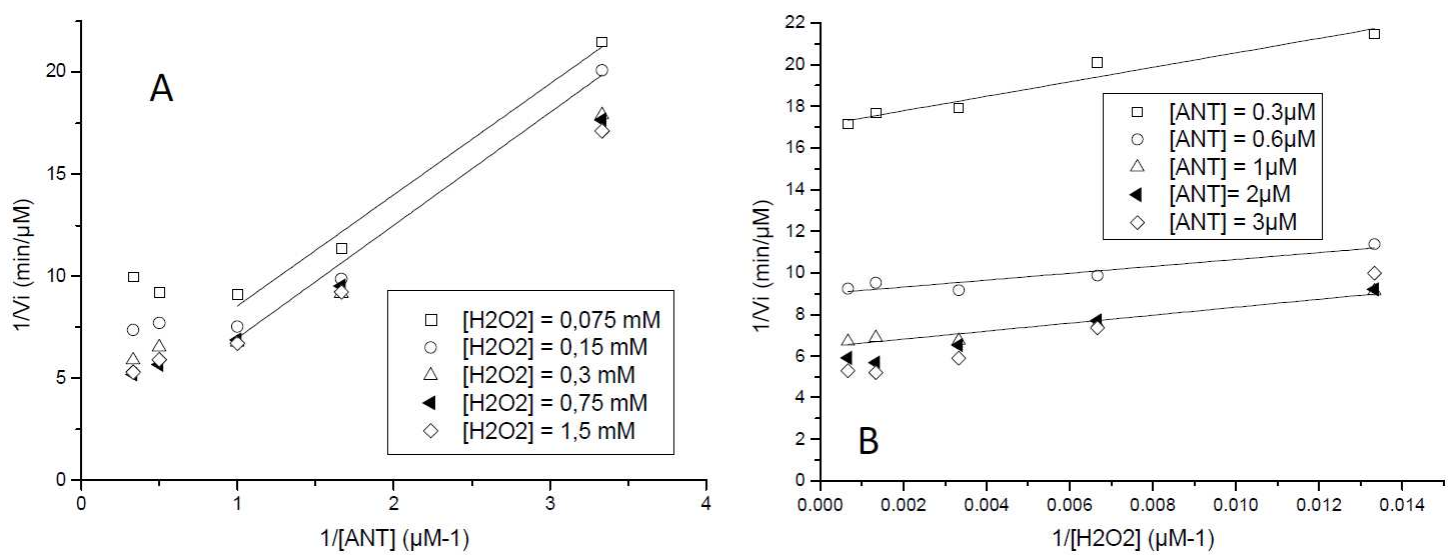

Fig 5 


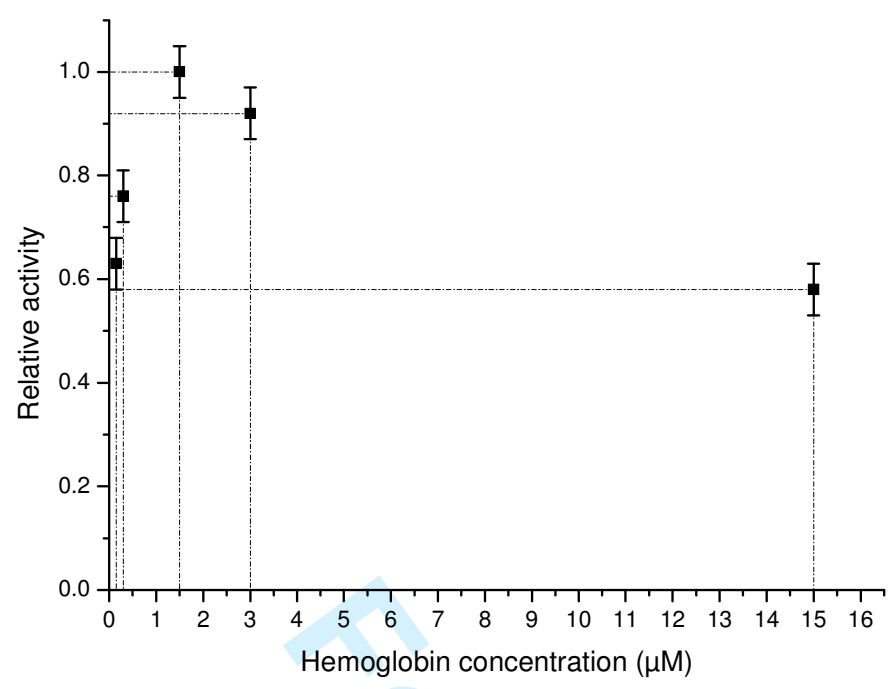

Fig $6 \mathrm{~A}$ and $\mathrm{B}$ 

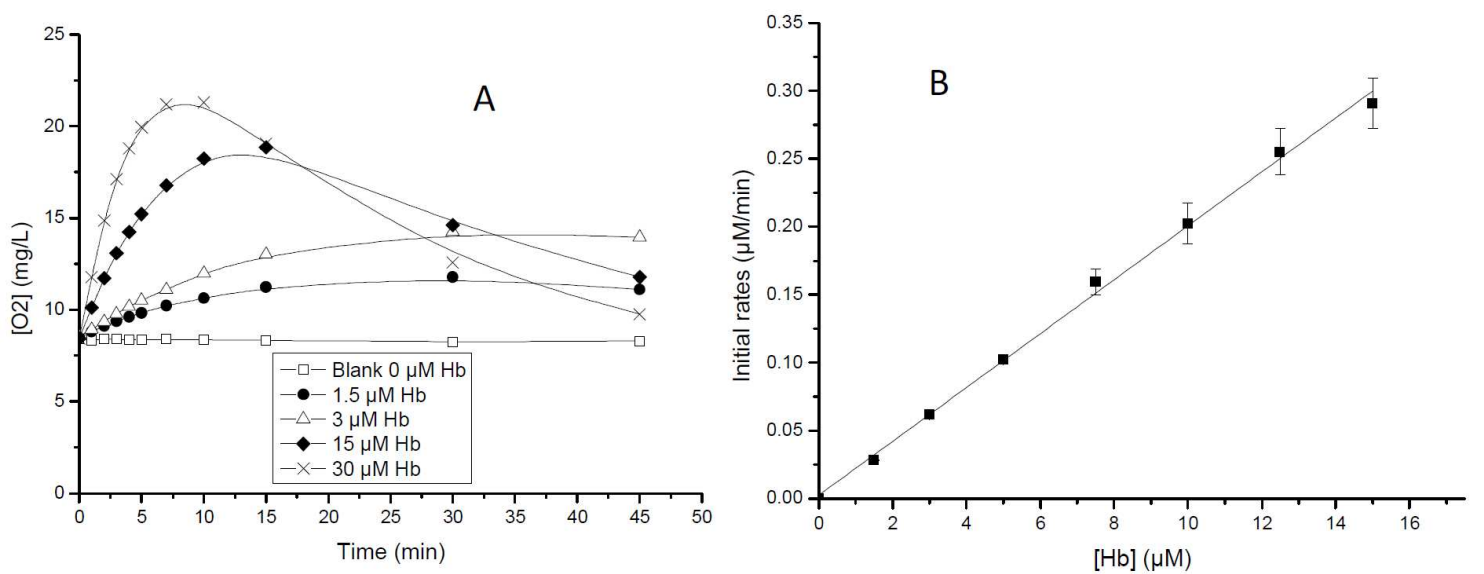

Figure $7 \mathrm{~A}$ and $\mathrm{B}$ 

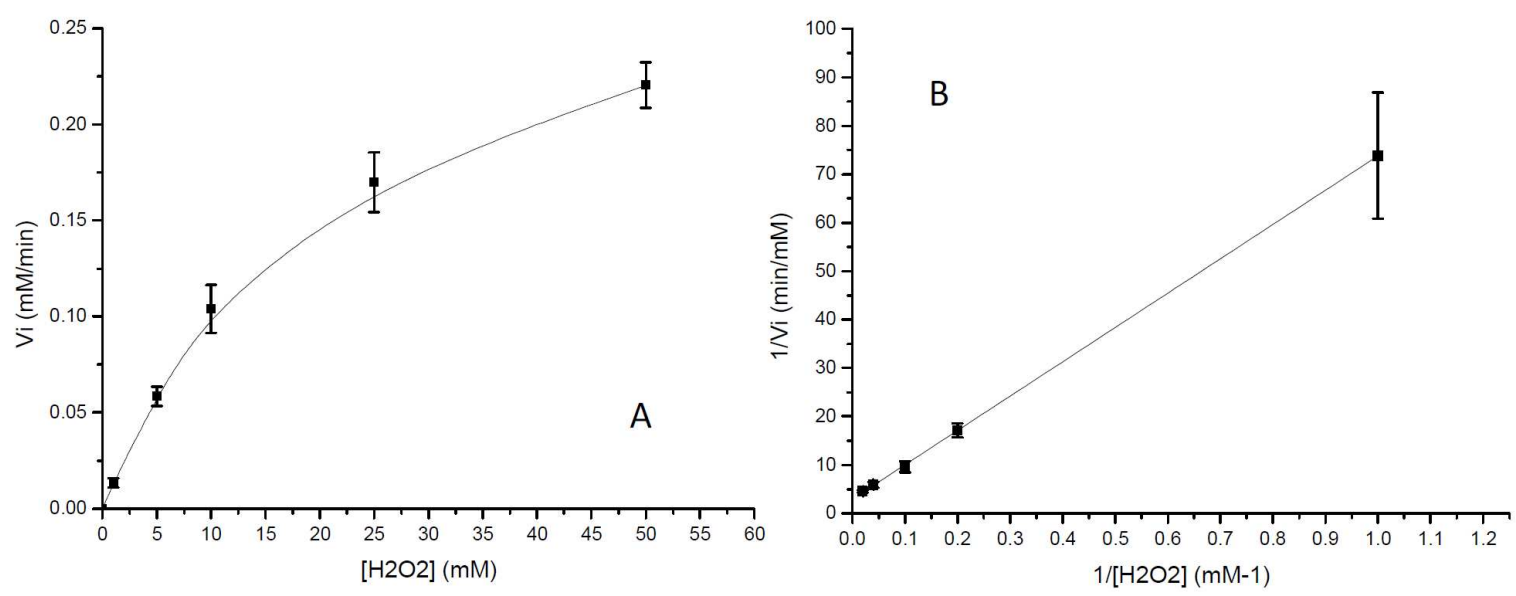

19

Fig 8 


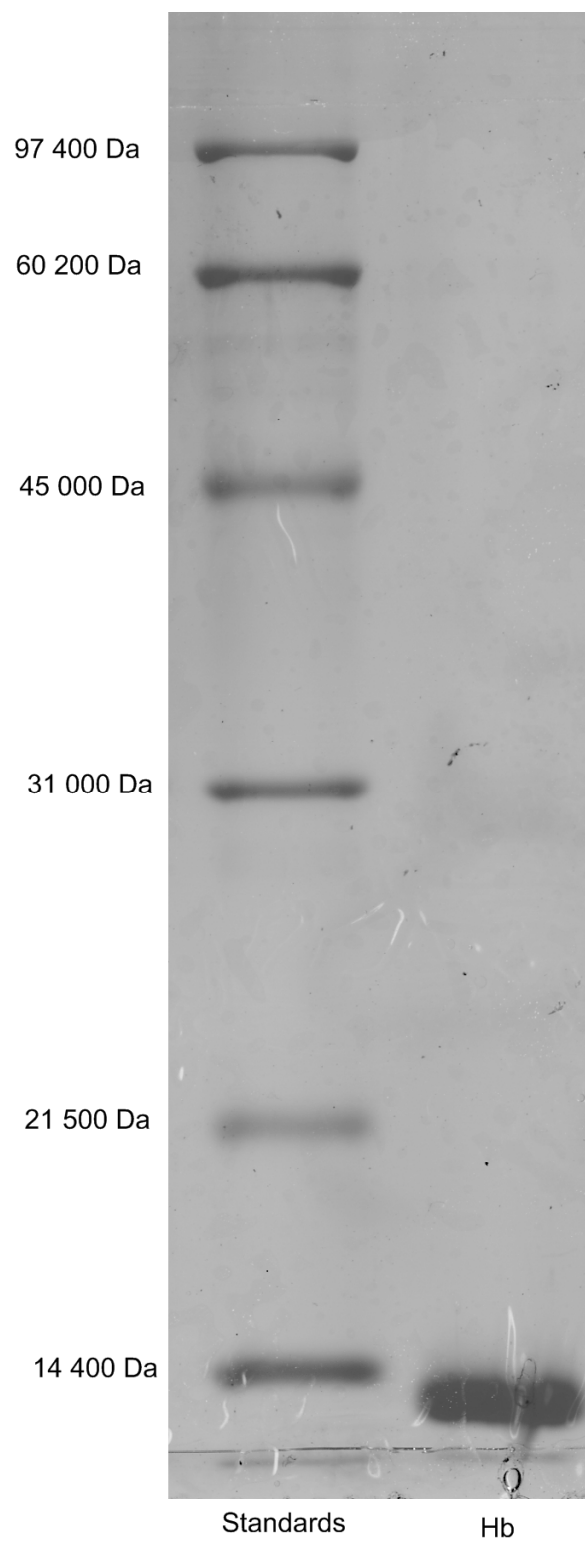

